Unchurched Christian Nationalism and the 2016 U.S. Presidential Election

Forthcoming at SOCIOLOGICAL FORUM

Samuel Stroope, Louisiana State University

Paul Froese, Baylor University

Heather Rackin, Louisiana State University

Jack Delehanty, Clark University

Acknowledgements: The authors thank Andrew Whitehead, Brad Storin, Jessica Stroope, Jim Garand, Joseph Baker, and Sam Amoroso for helpful feedback. 


\title{
Unchurched Christian Nationalism and the 2016 U.S. Presidential Election
}

\begin{abstract}
Prior research found that Christian nationalism was strongly associated with voting for Trump in the 2016 U.S. presidential election. However, the effects of Christian nationalism may depend on voters' religiosity. Using national data, we assess whether the association between Christian nationalism and Trump support differed for churchgoers and non-churchgoers and find that Christian nationalism is not significantly associated with Trump support among churchgoing voters. Instead, Christian nationalism is only significantly associated with Trump support among unchurched voters. These results suggest that while religious ideology remains a key driver of political attitudes and behavior in the U.S., its effects may have less to do with embeddedness in traditional religious organizations and more to do with the ways people use religious narratives in everyday life to construct and defend symbolic boundaries. At a time when fewer Americans attend religious services, religious narratives about Christian nationhood may have their strongest political effects when, and perhaps because, they are detached from religious institutions.
\end{abstract}

Keywords: religion, politics, Trump, religiosity, nationalism, secular 


\section{INTRODUCTION}

Much has been made of the role religion played in the unexpected election of Donald J. Trump as the $45^{\text {th }}$ president of the United States. While religious conservatives may have had the usual partisan reasons for voting for the Republican nominee, earlier indicators in the GOP primaries showed that Trump support was stronger among conservatives who infrequently or never attend religious services (Ekins 2018; Gorski 2017). Yet religious attenders were a major part of Trump's eventual victory in the general election (Huang et al. 2016). Closer analysis held that religious ideology also became a potent force over and above religious attendance, with Christian nationalism noted among the most salient factors in voting for Trump (Braunstein 2017; Gorski 2017; Whitehead, Perry, and Baker 2018). We seek to better understand this dynamic by examining the relationships between Christian nationalism, religious service attendance, and voting in the 2016 U.S. presidential election.

While there are reasons to expect that religious communities amplified the effects of Christian nationalism in 2016, Christian nationalism and religious involvement can be and often are distinct or unrelated (Braunstein and Taylor 2017; Whitehead and Perry 2020). We draw on insights from scholars who find that when religious sentiments detach from religious institutions, they can become more exclusionary, particularly with regard to the politics of national identity and belonging (Asad 2003; Brubaker 2017). Researchers working in different national contexts have found that as rates of religious attendance and membership in religious organizations erode, religious symbols and narratives often become key drivers of restrictive visions of national identity (Storm 2011). In France and Switzerland, bans on veiling and the construction of minarets rally cultural conservatives around the 'protection' of a national Christian heritage even as rates of Christian belonging and practice decline (Asad 2006). Likewise, in Turkey, scholars 
note the resurgence of Islamism under President Erdogan as more a cultural-political development than a purely religious one (Karakaya 2020). In the U.S., researchers find that Christian nationalism is linked to support for Trump (Whitehead et al. 2018), but it is not known whether this relationship is most operative within religious organizations, or outside of them.

These insights suggest that explaining the "religious vote" for Trump requires nuance, because personal religious practice and popular religious ideologies can have different sources and express different political contours. Using data from a 2017 national probability sample, we assess whether the relationship between Christian nationalism and Trump voting differed for those who regularly, occasionally, or never attend religious services. In doing so, we specify more precisely the relationship between Christian nationalism and Trump support, and extend theory about how religion affects society as religious institutions wane.

Previous literature shows that religious ideas and practices often spill out of religious institutional spaces into everyday secular life (Ammerman 2014; Delehanty, Edgell, and Stewart 2019; Gorski 2019). As religious ideas and symbolism merge into secular life, they often lose much of their ethical and theological complexity but retain their power to draw group boundaries (Braunstein 2017; Wuthnow 2012). In showing how Christian nationalism works differently among non-churchgoers ${ }^{1}$ compared to churchgoers, we provide a clear empirical example of this phenomenon. Our findings thus highlight a gap between religion, as it is practiced in local religious communities, and the religious symbolism and ideology of "lived religion" beyond the bounds of religious communities (Ammerman 2014). We argue that congregational

\footnotetext{
${ }^{1}$ We use "church" in a general sociological manner to denote religious congregations of various faiths. Most regularly attending Christian nationalist Trump voters are Christian.
} 
embeddedness nurtures religious concerns, social conservatism, and partisanship (Bean 2014), whereas a nationalist religio-political ideology disconnected from churches can become secularized, populist, and a powerful electoral draw for individuals who are detached from religious communities (Asad 2003).

\section{BACKGROUND}

As with all recent Republican presidential candidates, an important source of support for Trump in the 2016 presidential election was religiously active whites, particularly evangelical Protestants within that demographic (Margolis 2020). Trump's general election support from religious voters was not surprising given the well-known power of partisan identities in American politics (Margolis 2018). Substantial research suggests the influence of religious involvement on voting for Republican candidates operates through its cultivation of conservative political in-group identities and antipathy toward liberal out-groups (Wald and Calhoun-Brown 2018). Such frequently observed patterns reflect a durable bond between conservative religionists (particularly white Christians) and the Republican Party. In another sense, Trump's strength of support from observant religionists was somewhat surprising given his personal comportment, public scandals, impiousness, and lack of strong early condemnation of abortion and same-sex marriage (Margolis 2020).

In search of explanations for Trump's success, researchers point to a variety of factors that were likely at play leading up to the 2016 presidential election. Scholars have highlighted the role of social class and economic anxiety (Hochschild 2018). Others emphasized that a reservoir of conservative racial attitudes were activated in relation to Trump among key demographics in the electorate (Sides, Tesler, and Vavreck 2018). Relatedly, nativism, Muslim animus, and sexism were important (Braunstein 2017; Edgell 2017; Griffin and Teixeira 2017; 
Schaffner, Macwilliams, and Nteta 2018; Wayne, Valentino, and Oceno 2016). Religious participation and evangelical Protestant identification (especially among whites) were also linked to voting for Trump in 2016 (Smidt 2017). Whitehead et al. (2018) contend that Christian nationalism was an ideology that organized many of these factors yet played a distinct and powerful role for voters.

Scholars have long noted the importance of Christian and religious nationalism in American political and social life (Bonikowski and DiMaggio 2016; Gorski 2010, 2019). Growing research has shown how people's beliefs about America's Christian nationhood are related to an array of social and policy attitudes (Froese and Mencken 2009; Whitehead and Perry 2020). Christian nationalism is a "cultural framework" concerned with national heritage, boundary drawing, social order, embattlement, and conquest (Brubaker 2012, 2017; Whitehead and Perry 2020:x). Gorski (2020:109) explains that Christian nationalism is a somewhat flexible “deep story" of blood and apocalypse perhaps unwittingly secularized and set in populist language.

It would be reasonable to assume that the politics of Christian nationalism in 2016 was primarily a phenomenon within Christian institutions - a variety of well-known Christian leaders, churches, and organizations used Christian nationalist rhetoric and lent support to Trump. Whitehead and Perry's (2020:1) study of contemporary U.S. Christian nationalism, Taking America Back for God, opens with a Baptist church "sanctuary bursting with stars and stripes" in which a military uniformed speaker proclaims that God has "always been on [America's] side." Such church-based displays of religious nationalism are not hard to find and it would be reasonable to posit that "the 'religious vote' for Trump was primarily the result of Christian nationalism" (Whitehead et al. 2018:169). But the 2016 election may not be a 
straightforward story of religious communities coalescing around the Christian nationalist candidate. Though analysis showed that levels of voting for Trump in the 2016 presidential election were higher among evangelical Protestants than other major religious traditions (Margolis 2020), Whitehead and Perry (2020) are careful to point out that Christian nationalism is not equivalent to evangelicalism. Whitehead et al. $(2018: 151,166)$ go further and suggest that Christian nationalism may be politically salient outside of devout Christian circles, "beyond the Christian traditions of its origins," and "in a wide range of contexts."

Noting Christian nationalism's appeal as a cultural framework beyond religious communities, Gorski (2020:3) describes a "secularized” narrative and Delehanty, Edgell, and Stewart (2019) a "secularized evangelical discourse." As a part of this discourse, "the Christian nation myth can function as a symbolic boundary uniting both personally religious and irreligious members of conservative groups," and "can influence narratives and action beyond institutional religion" (Whitehead et al. 2018: 151, 166-167). Whitehead and Perry (2020:x) note that "many non-evangelicals (or non-Christians, for that matter) also hold strong Christian nationalist beliefs" and find that "some Christian nationalists can be quite secular." Further, in a national study of religion among Tea Party Movement members, Braunstein and Taylor (2017) found that Tea Partiers who were part of the Religious Right and those who were not, as well as Tea Partiers who were evangelicals and those who were religious "nones" all had similar levels of affirming "Christian-America" belief. These findings highlight the appeal of a religiopolitical ideology for the religiously disconnected, making it "especially critical to examine Christian nationalism ... in subcultures and social arenas both inside and outside of institutional religions" (Whitehead et al. 2018: 151, 166-167). We follow these insights and investigate the extent to which Christian nationalism operates differently for those inside and outside of 
religious institutions. Our analysis aligns with the trend in theory identified above, suggesting that religion's most dynamic effects on U.S. politics may have less to do with what happens inside churches than with how people — whether they are individually religious or not — use religious ideas to draw and impose boundaries around national identity (Edgell et al. 2016).

\section{The Politics of a Changing America}

Several interlocking trends may have contributed to a differential importance of Christian nationalism for voters who attend and those who do not attend religious services. Rapid demographic shifts and cultural upheavals have left many Americans feeling not only bewildered, but like they have become a marginalized cultural minority (Hochschild 2018; Jones 2016). These Americans' feelings of marginalization are evident in a variety of domains. As an expression of American traditionalism and exceptionalism, Christian nationalism is linked to Muslim animus, nativism, and conservative racial attitudes (Whitehead and Perry 2020:2, 3). Consequently, the current popularity of Christian nationalism may be more an aspect of a larger populist ethos of victimization, embattlement, and resentment and less a reflection of Christian devotion (Gorski 2020). As such, fears of demographic shifts, immigration, the spread of Islam, and cultural change become fused with Christian identity (Williams 2013), even for those lacking personal religious fervor. Further, given fading public tolerance for overt racial bias, many may invoke Christian identity, symbols, or morality rather than explicitly ground national belonging in ethnicity or race (Marti 2020).

Recent rapid demographic and cultural change has unsettled many white Americans in particular (Mutz 2018). News from the U.S. Census regarding the United States' coming "majority minority" status were widely disseminated throughout the media and matches the everyday perceptions of many Americans. Political psychologists find that when majority- 
minority trends are presented to people of various political orientations and ethnicities, people's attitudes often shift toward conservatism (Major, Blodorn, and Major Blascovich 2018). Two terms of the first African American president—who many members of the American public believed was Muslim and foreign born-likely amplified perceptions of these societal changes and signaled threats to a white Christian America (Braunstein 2017). In addition to demographic change, departures from traditional forms of marriage, intimate relationships, and sexuality have become more prevalent, in both popular culture and especially among cultural elites. Relatedly, a sense that American society is rapidly secularizing is widely felt among the public (Jones 2016).

The proportion of Americans reporting that anti-white discrimination is a problem has grown and recent years have also seen an increase in legal cases and high-profile media coverage related to perceived anti-white bias (Norton and Sommers 2011). The 2015 Supreme Court marriage equality ruling was also unsettling to many socially conservative Americans whose views have quickly become at odds with not only public opinion but also U.S. law. Many Americans now feel that they are victimized for expressing traditional values concerning marriage, sexuality, and gender identity (Kazyak, Burke, and Stange 2018). These Americans' feelings of marginalization are driven by changing demographic and cultural dynamics. The changes they lament have made it less acceptable for them — and for movement leaders who want to appeal to them — to make race, gender, and sexuality explicit themes in their resistance. Christian nationalism can be used to veil racial and anti-LGBT bias behind a language whose words are race- and sexuality-neutral, but whose meanings may not be. As such, Christian nationalism appeals to many who feel marginalized, regardless of how or whether they practice religion personally (Marti 2020).

These shifts help to explain why Christian nationalism has staying power amid the 
decline in institutional religious involvement in the United States. In recent decades, the share of Americans who are religiously unaffiliated increased from $8 \%$ to as high as $31 \%$ (Baker and Smith 2015; Burge 2020). And after decades of Christian decline and demographic change, white Christians are no longer a majority of the U.S. population—moving from $54 \%$ of the country to $43 \%$ from 2008 to 2016 (Jones 2016). Although shifts in religious identification have been far more dramatic than shifts in religious practice, declines in American religious practice have also become clear (Chaves 2017; Voas and Chaves 2016). Ebbs in religious participation are not limited to religious and political liberals, but are also substantial among religious and political conservatives (Ekins 2018; Voas and Chaves 2018). Religiously inactive portions of the Republican Party were early and strong sources of support for Trump in the Republican primaries (Ekins 2018). At the same time, waning institutional religion in society likely made religiously devout Republicans more willing to support an unconventional figure such as Trump out of a sense of desperation and urgency related to the place of Christianity in society and the threat posed by a Clinton presidency (Margolis 2020).

\section{Secularized Christian Nationalism}

While religious involvement is generally related to contemporary conservative politics overall, some theory and evidence suggests that detachment from religious communities may intensify conservative attitudes. Among conservatives, illiberal attitudes and affirmative white identity are often highest among those who attend religious services less frequently or who never attend services (Wald and Calhoun-Brown 2018:12). For example, this pattern is observed for attitudes toward racial/ethnic and religious minorities and immigrants (Ekins 2018).

Conservatives who do not want their exclusionary attitudes softened may also eschew religious institutions and seek out support for their views elsewhere. Though disengaged from a local 
religious congregation, many may retain nominal affiliations with a religious tradition, perhaps as an ethnoreligious identity or marker of "secular Christianity" (Voas and Day 2010:1).

Religious detachment can play a similar role at the intersection of Christian nationalism and Trump voting. Specifically, the connection between Christian nationalism and Trump voting may be weaker for churchgoers and stronger for non-churchgoers because Christian nationalism has two faces. One face reflects the concerns of right-wing media consumers who lump together a wide range of "us" against "them" ideology merging white, Christian, rural, and Englishspeaking identities into a "true" American narrative (Whitehead and Perry 2020:2, 3). This face also reflects "nostalgia voters" and others who long for a bygone America characterized by community solidarity around cultural homogeneity—a Christian America (Carney 2019; Jones 2016:247). The other face of Christian nationalism denotes the concerns of socially conservative religionists, who fear waning religiosity and sexual morality and hope that political leaders can slow or reverse this decline. Participants in religious institutions tend to align with this second face of Christian nationalism, which is less characterized by the raw ethno-religious exclusion, nativism, and acrimony of the right-wing media landscape (but see Tranby and Hartmann 2008; Wald and Calhoun-Brown 2018:12; Whitehead and Perry 2020:4).

Additionally, relatively secular religious nationalists likely prefer more secular religious nationalist political candidates. Research finds that voters tend to prefer a candidate whose religiosity is perceived to match their own (Castle et al. 2017). Trump's policy ideas and rhetorical hostility to non-Christians and non-Americans and his nods to Christian nostalgia may be especially effective in attracting voters detached from the social and political milieu of religious communities yet who resonate with Christian nationalist tropes. In their analysis of Trump support, Whitehead et al. (2018: 166) note the "power of Christian nationalist rhetoric 
regardless of personal piety." We extend this idea further to assert that Christian nationalism may be powerful precisely because of a lack of personal piety.

\section{Unchurched Alienation}

Alienation and desperation felt by Christian nationalists are likely stronger for nonattenders compared to church attenders. This may be due to the simple reason that social solidarity within religious congregations can buffer against an array of stressors, in part, because of the shared beliefs, experiences, and valued forms of support found in congregations (Schieman, Bierman, and Ellison 2013). For example, researchers find that perceived antireligious sentiment in the media is more distressing to individuals who do not regularly attend religious services compared to regular attenders (Stroope, Walker, and Franzen 2017). So while many churchgoers feel marginalized in contemporary culture and experience stress when they sense threat to their deeply-held values (Bierman 2010; Parker and Barreto 2014), at least they belong to communal groups where they can experience routine social support, affirmation, and belonging. In contrast, religiously detached Christian nationalists may have more acute feelings of alienation because they are detached from religious communities. Consequently, unchurched Christian nationalists will be more likely to favor an authoritarian figure using populist appeals, exclusionary rhetoric, and religious nostalgia. As Gorski (2017:350) notes, "loosed from its religious moorings, religious nationalism floats free of the ethical tether of Christian ethics" and "drift[s] even further in the direction of secular messianism and political authoritarianism."

In American politics overall, and especially among conservative political leaders and media figures, religious language has become infused with political messaging in recent decades (Domke and Coe 2010). And as right-wing social and news media became increasingly popular, church attendance rates have declined. Consequently, conservatives may more easily use their 
political media consumption not only as a form of political identity but also as a source of moral community. While church membership remains a dominant force in explaining AfricanAmerican political participation, the role of churches is much less important to white political action (Liu, Austin, and Orey 2009). This has long been the case for whites, but what has changed is the intensity of religious nationalist rhetoric coming from white conservatives outside of religious institutions.

The internalization of divisive rhetoric from media sources and public figures combined with a lack of institutional support leave unchurched Christian nationalists particularly isolated and vulnerable to feelings of marginalization. Indeed, recent research on white Americans suggests that religious detachment tends to correspond with other forms of social detachment including from higher education, work, and marriage (Edin et al. 2019; Wilcox et al. 2012). These dynamics align with what some have called the "Christian penumbra," a label for nonpracticing Christians who are disconnected from communal support and who experience frustration and distress in a variety of domains - a group that strongly supported Trump in the GOP primaries (Carney 2019; Douthat 2014; Lim 2015).

In sum, Christian nationalism may be complex in its political potency for different groups of Americans. Many churchgoers naturally hope that their religious identity is reflected in national culture and federal law. Yet the power of political partisanship and social conservatism may have overshadowed the ethnoreligious exclusion of Christian nationalism for these voters. For unchurched voters, the fusion of Christian America nostalgia with exclusionary boundary marking in political rhetoric may have led to championing an idealized religious culture that they themselves do not experience within religious communities. Free from the strictures and support of religious communities, these unchurched voters were especially roused by religio-nationalist 
sentiments in their embrace of resentment politics and Trump's candidacy.

\section{DATA AND METHODS}

To assess these dynamics, we use wave 5 of the Baylor Religion Survey (BRS), an ongoing cross-sectional national probability sample regularly administered in partnership with the Gallup Organization since 2005, and comparing favorably with the GSS (Bader, Mencken, and Froese 2007; Froese 2017). These data are important for the topic at hand; the survey was fielded shortly after November 2016 and is the only national sample from this time with a six-item Christian nationalism scale, religion measures, and voting behavior. The survey relied on an Address Based Sample (ABS) methodology due to emerging issues related to telephone-based samples (AAPOR 2016; Kennedy and Harting 2019; U.S. Census Bureau 2014). Selfadministered mail surveys were sent to 11,000 addresses and were followed biweekly by two sets of reminders, resulting in 1,501 respondents. $^{2}$ After excluding non-voters $(N=259)$, we used the mi multiple imputation routine in Stata 16 (20 datasets) to recover missing values on independent variables (analytic sample $N=1,242$ ). Analyses used Stata 16 and applied the BRS sampling weight.

\section{Dependent Variable}

Voting for Trump. Respondents were asked, "For whom did you vote in the 2016 presidential election?" Responses were coded such that "Donald Trump, the Republican candidate" was coded as "1" and "Hillary Clinton, the Democratic candidate," or "Someone

\footnotetext{
${ }^{2}$ A response rate of $13.6 \%$ is above average for public opinion surveys around this time period and estimates of political and religious characteristics in these surveys remain similar to highresponse rate surveys such as the GSS (Keeter et al. 2017).
} 
else" was coded as "0." Results were similar in analyses where the outcome was structured such that those coded as " 0 " included both non-Trump voters and non-voters (available upon request).

\section{Explanatory Variables}

Christian nationalism $(C N)$. Following previous work, we measure $\mathrm{CN}$ using a summative index developed in the BRS to measure the extent to which respondents think that it is the federal government's job to promote and advocate overtly religious and Christian ideas, symbols, and activities (Froese and Mencken 2009; Whitehead et al. 2018). The index is comprised of six items with response options of 1 "strongly disagree," 2 “disagree," 3 "don't know," 4 "agree," and 5 "strongly agree": (1) “The federal government should declare the United States a Christian nation"; (2) “The federal government should advocate Christian values"; (3) "The federal government should enforce strict separation of church and state" (reversed); (4) "The federal government should allow the display of religious symbols in public spaces"; (5)

"The success of the United States is part of God's plan"; and (6) "The federal government should allow prayer in public schools.” The index ranged from 6 to 30 with a mean of 17 . After centering on the mean, the resultant variable ranges from -11 to 13 with higher values indicating greater Christian nationalism $(\alpha=.86)$.

Religious service attendance is measured as a categorical variable: (1) non-churchgoers (28.4\%) (reference); (2) occasional churchgoers ("less than once a year" to "several times a year" [29.2\%]); and (3) regular churchgoers ( $\geq$ once a month [42.4\%]). The theoretical backdrop of this study distinguishes between Americans who are detached from religious congregations and those who are embedded in religious congregations. As such, the visual presentation of our results focuses on differences between non-churchgoers and regular churchgoers.

\section{Covariates}


We adjust for potentially confounding covariates in regression analyses. ${ }^{3}$ We include two quantitative measures of private religiosity: Frequency of praying alone outside religious services (range: 1 "never" to 7 "several times a day"); and frequency of scripture reading outside religious services (range: 1 "never" to 5 "several times a week"). Biblical literalism is measured as $1=$ "the Bible ... should be taken literally ...," else 0 . Religious affiliation is classified using five categories: evangelical Protestant, mainline Protestant, Catholic, other faith, and none, based on the RELTRAD scheme (Dougherty, Johnson, and Polson 2007; Steensland et al. 2000).

${ }^{3}$ Our variable coding differs from Whitehead et al. (2018): service attendance, prayer, and scripture reading are measured separately; education and urbanicity are both categorical and we measure them as such; to avoid discarding information, anti-immigrant sentiment is ordinal rather than dichotomized; and we add region due to its importance as a control in religionpolitics research. We collapse some categorical variables due to empty Trump-voter cells among non-attenders which otherwise caused perfect prediction and non-convergence in multiple imputation despite repeated attempts and use of recommended augmentation procedures: black Protestant is collapsed into "other faith," Bible views into biblical literalism, and race into nonHispanic white. We find substantively similar results as those shown here in ancillary models (available upon request) where attendance is not used in multiple imputation and coding otherwise matches Whitehead et al. (2018). The non-interacted effect of Christian nationalism is similar to model 1 (odds ratio $=1.11 ; p=.06$ ), the effect of Christian nationalism for nonattenders is similar to model 2 (odds ratio $=1.30 ; p<.001$ ), and the focal interaction term remains statistically significant (odds ratio $=.75 ; p<.001$ ). 
Sociodemographic controls include: age (range: 17 to 98$)$; female $(1=$ yes); non-Hispanic white $(1=$ yes $)$; married $(1=$ yes); and educational attainment (less than high school, high school graduate [reference], some college, and college degree or more). Income ranged from (1) “\$20,000 or less” to (6) “\$150,001 or more.” Urbanity (rural, small town, suburb near city, and large city [reference]), and region (West, South, Midwest [reference], Northeast) were also controlled. We measure party affiliation as: Republican (reference), independent, and Democrat. Political conservatism ranged from "extremely liberal" (1) to "extremely conservative" (7). In addition, we adjust for several factors thought to be salient in 2016 and that might confound key associations (Whitehead et al. 2018). We include an index of anti-Muslim attitudes comprised of four items measuring views of Muslims as holding "values that are morally inferior to the values of people like me," limiting the "personal freedoms of people like me," "endanger the physical safety of people like me," and Middle Eastern refugees posing "a terrorist threat to the United States" $(\alpha=.91)$. Undocumented immigrant attitudes is based on respondents' agreement that, "Illegal immigrants from Mexico are mostly dangerous criminals" (range: "strongly disagree" to "strongly agree"). To control for anti-black attitudes, we use an index of two items measuring respondents' agreement with statements about police officers (range: "strongly disagree" to "strongly agree"): (1) "treat blacks the same as whites"; and (2) "shoot blacks more often because they are more violent than whites." Despite a low $\alpha$ of .43, we follow prior work and index these items (separating the items does not alter results). Gender ideology combines four variables pertaining to women's suitability for politics, mothers working outside the home, God's will that women care for children, and that husbands should earn more than wives $(\alpha=.77)$. Finally, we control for respondents' satisfaction with their household's current financial situation (range: "not at all satisfied" to "completely satisfied"). 


\section{Analytic Method}

First, we graph the trivariate distribution of Trump voting across four levels of Christian nationalism, by religious attendance. Second, we regress Trump voting on independent variables to show main effects, net of controls. Third, we add an interaction of Christian nationalism by religious attendance. Interpreting interaction effects in logistic regression is considerably more complex than in OLS regression and researchers cannot rely on the statistical significance, size, or direction of an interaction term coefficient; as such, we apply methods outlined by Mize (2019). First, we graph the average marginal effect (AME) of Christian nationalism across church attendance, net of controls. Second, because the effects of religious nationalism may be contingent upon political self-perceptions (Astor and Mayrl 2020:15), we graph predicted probabilities for substantively important subgroups in the electorate based on party affiliation and political identity, net of controls. We include graphs of moderates (among Democrats, independents, and Republicans) as moderates are likely least governed by political identity in their voting behavior.

\section{RESULTS}

Figure 1 presents the trivariate distribution of percent Trump voting across religious attendance, and four levels of Christian nationalism. The graph shows that, for all levels of religious attendance, with each higher level of Christian nationalism $(\mathrm{CN})$, the percent voting for Trump increases, with the increase most pronounced among non-attenders. Comparing regular attenders to non-attenders, the percent voting for Trump increases from low-CN to high-CN by 58 points for regular attenders and 79 points for non-attenders.

\section{***FIGURE 1 ABOUT HERE***}

Table 1 shows variable distributions and results from logistic regression models. Model 1 
shows the main effects of explanatory variables. In this model, $\mathrm{CN}$ has a positive relationship with Trump voting but does not reach statistical significance $(b=.090 ; p=.062) .{ }^{4}$ Compared to not attending religious services, occasional attendance has a negative relationship with Trump voting $(b=-.606 ; p=.208)$ and regular attendance a positive relationship $(b=.140 ; p=.802)$, but neither are statistically significant. In Model 2, CN is interacted with religious service attendance. $^{5}$ The lower order effect of $\mathrm{CN}$ (i.e., the effect for those who do not attend services) is positive and statistically significant $(p<.001)$. The association is also large and substantively important. For non-attenders, a one-standard deviation increase in $\mathrm{CN}$ results in more than 5 times greater odds of Trump voting (exp[.244 x 6.648]=5.06). In ancillary models (available

${ }^{4}$ In ancillary models available upon request, the association between Christian nationalism (CN) and Trump voting is positive and statistically significant $(b=.124 ; p=.004)$ when anti-Muslim attitudes and anti-immigrant attitudes are omited. The $\mathrm{CN}$ effect diminishes when anti-Muslim attitudes is added (but omitting anti-immigrant attitudes) $(b=0.10 ; p=.034)$, as it does adding anti-immigrant attitudes (but omitting anti-Muslim attitudes) $(b=.105 ; p=.021)$. When we add anti-Muslim and anti-immigrant simultaneously, the $\mathrm{CN}$ effect diminishes further and becomes non-significant $(b=.09 ; p=.062)$. These results are consistent with Whitehead et al.'s (2018:164) suggestion that Christian nationalism has indirect effects on Trump voting through negative views of ethnic "others."

${ }^{5}$ The Christian nationalism by regular attender interaction term is marginally significant without control variables in the model $(p=.09)$. The interaction becomes significant with the inclusion of any of several variables including race, income, urbanicity, political conservatism, party affiliation, or anti-Muslim attitudes. 
upon request) we rotate the reference category to test the association between $\mathrm{CN}$ and Trump voting for occasional and regular religious service attenders, net of control variables. $\mathrm{CN}$ has no statistically significant association with Trump voting ${ }^{6}$ for either category of religious attender (occasional attender: $b=.106 ; p=.232$; regular attender: $b=-.030 ; p=.574$ ). ${ }^{7}$ The only group for which $\mathrm{CN}$ has a significant and positive relationship with Trump voting is non-churchgoers. So, we have evidence that as non-churchgoers' CN rises so do the odds of voting for Trump. For occasional attenders we do not have evidence to know whether the effect of $\mathrm{CN}$ is significantly different from zero (odds ratio $=1.11 ; p=.232$ ). For regular attenders, there is some evidence that the $\mathrm{CN}$ relationship with Trump voting is a flat slope since it is very close to zero (odds ratio $=0.97 ; p=.574)$. Figure 2 , Panel A presents the average marginal effects (AME) of all respondents in model 2 and second-difference significance tests with significant group differences between regular attenders and non-attenders shown using solid lines and nonsignificant differences using hashed lines. The graph shows that regular attenders were more likely to vote for Trump compared to non-attenders at low-to-mid levels of CN. As CN increases, so do non-attenders' levels of Trump voting and they converge with regular attenders' Trump support at high levels of CN.

As noted earlier, moderates are likely to be the least influenced by political identity in their voting behavior, and hence we plot their predicted probabilities for Republicans (Panel B),

${ }^{6} \mathrm{CN}$ is also not statistically significant for occasional or regular attenders in ancillary models (not shown) where Trump voting is coded such that $0=$ non-Trump voters and non-voters. ${ }^{7}$ The regular attender $\mathrm{CN}$ effect is significant until either party affiliation or conservatism are added and the effect is reduced to non-significance (available upon request). 
independents (Panel C), and Democrats (Panel D) in Figure 2. ${ }^{8}$ Focusing on independents in Panel C, it is noteworthy that at low levels of CN, the pattern is similar to that of Panel A, with Trump voting higher among regular attenders but with non-attenders catching up as $\mathrm{CN}$ increases and the two groups eventually converging. Moderate independents (Panel C) differ from the AME pattern in Panel A in that for moderate independents the attender versus nonattender probabilities of Trump voting converge at average levels of $\mathrm{CN}$ rather than converging at high CN as they do in Panel A. Also, in Panel C, non-attenders' probability of Trump voting surpasses that of regular attenders at high levels of $\mathrm{CN}$ and this group difference is statistically significant in second-difference tests. The divergence is also substantial. With covariates held at their observed values, for the most Christian nationalist voter, the predicted probability of Trump voting for a moderate independent regular attender is . 385 . If the same person were a nonattender, their predicted probability would be .799 , leading to a difference in the predicted probability of .415-a very large difference $(p=.005)$.

\section{***TABLE 1 ABOUT HERE*** \\ ***FIGURE 2 ABOUT HERE***}

Beyond these results, several other patterns are noteworthy in Model $1 .{ }^{9}$ Non-Hispanic

\footnotetext{
${ }^{8}$ Generally positive slopes are found among non-attenders and close to zero for regular attenders for liberal and conservative Republicans, liberal and conservative independents, and conservative Democrats (graphs available upon request).

${ }^{9}$ Prayer and scripture reading are also significant, but analyses suggested the presence of multicollinearity. These effects should not be interpreted with certainty, though including them as control variables is not problematic (Allison 2012).
} 
white race, income, political conservatism, anti-Muslim attitudes, and anti-undocumented immigrant attitudes are significantly associated with greater odds of Trump voting. "Other faith" (compared to evangelical Protestant) and independent and Democrat political affiliations (compared to Republican) were significantly associated with lower odds of Trump voting. ${ }^{10}$

\section{DISCUSSION}

The effects of religion on electoral politics are diverse. People who are more religious tend to have conservative political identities and policy attitudes, especially with regard to social conservatism (Leege and Kellstedt 1993; Wilcox and Robinson 2011). Yet religious beliefs and practices are also associated or compatible with certain liberal attitudes, such as support for some social justice initiatives and opposition to the death penalty (Braunstein, Fuist, and Williams 2017; Franzen 2013; Steensland and Goff 2013; Thomson and Froese 2018). Congregational research finds little partisan politics actively preached from the pulpit (Chaves 2004), which has led some researchers to maintain that strong political cultures within churches are mainly guided by congregants and lay leaders, and not ministers (Bean 2014; Bean and Martinez 2015). Yet, religious rhetoric on the campaign trail has steadily grown since the 1980s (Domke and Coe 2010), suggesting that politicians garner support when they make religious appeals. Christian nationalism has been a feature of American politics over the years and was involked repeatedly leading up to the 2016 U.S. election (Whitehead et al. 2018).

The complex relationship between religion and politics in the United States is made clearer by the two faces of Christian nationalism. On one side is how religion is often discussed in political and media discourse and among Americans who feel alienated amid societal change.

\footnotetext{
${ }^{10}$ In ancillary models, "other faith" is non-significant when black Protestants are separate.
} 
In this sphere, Christian-America rhetoric has become synonymous with nostalgia, ethnoreligious boundary work, and right-wing populism (Whitehead and Perry 2020, chapters 2 and 3). This is reflected among alienated Americans who feel politically disenfranchised and who long for identity, belonging, and shared culture - nostalgia voters who feel that reclaiming a bygone Christian America will make America great or at least feel more like home again (Carney 2019; Jones 2016). It is also reflected in the language of right-wing media (e.g., talk radio, FOX News, etc.) and Trump himself. Further, white nationalist groups in the U.S. explicitly use Christian nationalist rhetoric, but those who identify with such movements tend not to be strongly involved in mainstream Christian congregations. Unchurched Christian nationalist Trump voters may be a group that is attracted to the goals and rhetoric of white nationalism, a movement which utilizes Christian language to provide moral legitimacy to its secular causes (Aho 2016). Accordingly, many Christian nationalists view a generic Christian identity, and not necessarily religious practice, scriptural knowledge, nor even church membership, as the key religious aspect of being a "true" American. The other face of Christian nationalism tracks with the politics of religious communities; here, religion is durably tied to socially conservative attitudes and policies (Whitehead and Perry 2020, chapter 4). Long-established partisan identities and norms of Republican voting among religious communities are operative. ${ }^{11}$ However, churchgoing and Christian nationalism are not mutually amplifying.

Our results show that Trump support was robustly tied to Christian nationalism in the 2016 presidential election. Yet, we find no evidence that Christian nationalism mobilized churchbased support in the election. This is demonstrated by the fact that in our results Christian

\footnotetext{
${ }^{11}$ This is not true for a number of racialized religious groups (O’Brien and Abdelhadi 2020).
} 
nationalism is only strongly associated with Trump support for voters who do not attend religious services. Among religious attenders, the effect of Christian nationalism on Trump voting is not only weak, it is also not statistically different from zero. On average, non-attenders have lower odds of Trump voting than attenders at low levels of Christian nationalism, and nonattenders converge with attenders at mid to high levels of Christian nationalism. But for many subgroups in the electorate, attenders and non-attenders cross over each other and diverge at higher levels of Christian nationalism such that non-attenders' probability of Trump voting significantly surpasses that of religious attenders. In short, Christian nationalism predicts Trump voting for the unchurched, but not for churchgoers. And unchurched Christian nationalists' probability of Trump voting often exceeds that of churchgoing Christian nationalists. This study's findings substantially clarify connections between Christian nationalism, local religious communities, and Trump support and reveals an important relationship otherwise obscured.

How would unchurched individuals come to embrace Christian nationalist beliefs? And why would disconnection from communal religious involvement ${ }^{12}$ amplify Christian nationalist Trump support? Christian nationalism reverberates faintly Christian themes that have been widely diffused in contemporary American culture, "so much so, in fact, that one could probably internalize them without any formal exposure to Christian teachings" (Gorski 2017:177). For some, "Christian" is "culturalized" and is largely an ethno-cultural marker detached from congregational ritual or theology (Astor and Mayrl 2020; Storm 2011). In these instances, individuals identify strongly with "religious" politics and symbols while having little conventional religious involvement themselves. When religious observance recedes in society, related forms of purposeful belonging and meaning-making such as imagined ethno-national

${ }^{12}$ Churchgoers tend to also have interpersonal social ties at church (Stroope 2012). 
communities can fuse with "a residue of faith that, while no longer tied to active observance, still affords a sense of communal belonging" (Astor and Mayrl 2020:9). If being an active member of a local church has long been a sign of being a good citizen, for the unchurched, embracing Christian nationalism, and coalescing in movement-based communities around charismatic political figures who express it, as Trump does, may be a way to express a "fuzzy fidelity," assuage alienation, and re-assert a sense of status and national belonging (Braunstein and Taylor 2017; Voas and Day 2010:3).

In times when it is more difficult to openly espouse the view that illiberal whites are the "true" or archetypal Americans, affirming Christian nationhood places a mythical or even sacred sheen on ethno-racial, religious, and cultural homogeneity. This may be why Christian-America beliefs detached from embeddedness in religious communities fit seamlessly with Trump's nationalist populism. Along with being unmoored from religious communities, this face of Christian nationalism gives a Christian gloss to a desire to exclude religious or ethnic "others" from the American project or at least to return to an illusory time of shared cultural belonging (Gorski 2011; 2018).

Our pattern of findings is not without analogy in other nations where nationalist populism has mingled with religious symbolism amid societal secularization. Focusing on the European context, Brubaker $(2017,1199)$ writes, "it is precisely the ongoing erosion of Christianity as doctrine, organization, and ritual that makes it easy to invoke Christianity as a cultural and civilizational identity, characterized by putatively shared values that have little or nothing to do with religious belief and practice." This point is supported by research showing how conservative parties and leaders in Europe have used religious symbols to define national identity and belonging, even while religious disaffiliation continues apace (Asad 2003, 2006; 
Hervieu-Léger 2006; Karakaya 2020).

Still, overall Christian nationalist beliefs are most prevalent among observant Christians (Whitehead and Perry 2020), though the current study does not find robust evidence that these beliefs directly translate into increased support for Trump among churchgoers (who had a variety of other reasons for voting for Trump in 2016). Never fully contained within religious institutions, Christian-America narratives were cultivated by anti-New Deal business elites in a different era (in concert with religious leaders) (Kruse 2015), and in recent years a spillover of Christian-America rhetoric has taken on a life of its own within American political life outside of religious institutions (e.g., the Tea Party) (Braunstein and Taylor 2017). In one sense, the salience of such unchurched religio-nationalist sentiment appears odd. However, researchers have long noted that lack of institutional religious participation does not equate to religious antipathy and secularization may not necessarily augur a more liberal or less nationalist politics. It may do the opposite (Gorski 2020). Simply put, we find that a lack of churchgoing does not necessarily mean that a person does not ascribe to religiously-rooted boundaries of national identity and belonging; indeed, we find that some non-churchgoers appear to be more strongly motivated by such boundaries compared to regular churchgoers.

Our findings may seem incongruous with evidence that a backlash against the fusion of religion and conservative politics fueled the rise in religious "nones" (i.e., religiously unaffiliated individuals) (Djupe, Neiheisel, and Conger 2018). However, nones are politically complex and theistic nones are more likely than non-theistic nones to affiliate with the Republican party or have a conservative identity (Baker and Smith 2015; Schwadel 2020). Further, while nearly onequarter of nones report that they attend religious services on some regular/periodic basis, nearly half of people who report they never attend religious services nevertheless report some type of 
religious affiliation. ${ }^{13}$ In short, religious affiliation, religious participation, and political identity are not neatly coterminous. A seeming incongruity between nones-politics research and the current study may in fact point to the politics of a soft secularism, a growing potential constituency for conservative political movements going forward (Schwadel 2020).

One important caveat to our results and interpretations is their dependence on the qualities of particular religious communities in the contemporary U.S. The extent to which religious communities' nationalism is or is not tied to exclusionary or authoritarian politics may be of "limited guidance" based on values and norms salient in religious groups at a given place and time (Wald and Calhoun-Brown 2018:335). A limitation of the current study is its lack of contextual granularity and limited sample size. Future research can better explore temporal-, community-, and tradition-specific contingencies of different facets of religious nationalism using larger samples to understand the extent communities and groups actively support or oppose pluralistic democratic views, policies, and political candidates. In these instances, religious detachment may or may not amplify a religio-nationalist politics. The study's sample size places a limitation around cell sizes for some joint distributions of variables in the study; larger samples can enhance future analyses. Nevertheless, all combinations of categories are populated in the current data, and the cell sizes of combinations are built into the regression models' estimates of uncertainty. Some small groups such as non-attending staunch Christian nationalist Trump voters may be consequential groups of voters. Many elections are determined by small margins.

The election of Donald Trump revealed new ways in which religion can influence politics in the United States. Religious ideology as reflected in right-wing media and by Republican

\footnotetext{
${ }^{13}$ Author's calculations based on the BRS-5.
} 
candidates may have attracted many voters precisely because they were not religiously observant. Nationalist and ethnic ideologies which entwine with a faith tradition can artificially inflate religious identities (Astor and Mayrl 2020). Under these circumstances, religion functions as an implement of national belonging, or more narrowly, of a political movement. Christian nationalism continues to portend in Americans' political intentions (Baker, Perry, and Whitehead 2020). If Christian-America sentiments help mobilize unchurched voters, they may increasingly be a tool used in conservative political coalition building amid declining religiosity. The putative religious basis for Trump's 2016 victory may really tell of a larger story about religious identities becoming a salve for alienation in a changing America. In an age when fewer Americans attend religious services, religious sentiments — even when detached from religious institutionsremain an important force in American politics. 


\section{REFERENCES}

AAPOR. 2016. Address-Based Sampling. American Association for Public Opinion Research. Aho, James Alfred. 2016. Far-Right Fantasy: A Sociology of American Religion and Politics. New York, NY: Routledge.

Allison, Paul D. 2012. "When Can You Safely Ignore Multicollinearity?” Statistical Horizons. Retrieved August 13, 2020 (statisticalhorizons.com/multicollinearity).

Ammerman, Nancy T. 2014. "Finding Religion in Everyday Life.” Sociology of Religion 75(2):189-207.

Asad, Talal. 2003. Formations of the Secular: Christianity, Islam, Modernity. Stanford, CA: Stanford University Press.

Asad, Talal. 2006. "French Secularism and the 'Islamic Veil Affair." The Hedgehog Review 8(1):93-107.

Astor, Avi, and Damon Mayrl. 2020. "Culturalized Religion: A Synthetic Review and Agenda for Research." Journal for the Scientific Study of Religion.

Bader, Christopher D., F. Carson Mencken, and Paul Froese. 2007. “American Piety 2005:

Content and Methods of the Baylor Religion Survey." Journal for the Scientific Study of Religion 46(4):447-463.

Baker, Joseph O., Samuel L. Perry, and Andrew L. Whitehead. 2020. “Keep America Christian (and White): Christian Nationalism, Fear of Ethnoracial Outsiders, and Intention to Vote for Donald Trump in the 2020 Presidential Election." Sociology of Religion 81(3):272293.

Baker, Joseph O., and Buster G. Smith. 2015. American Secularism: Cultural Contours of Nonreligious Belief Systems. New York, NY: NYU Press. 
Bean, Lydia. 2014. The Politics of Evangelical Identity: Local Churches and Partisan Divides in the United States and Canada. Princeton, NJ: Princeton University Press.

Bean, Lydia, and Brandon C. Martinez. 2015. "Sunday School Teacher, Culture Warrior: The Politics of Lay Leaders in Three Religious Traditions." Social Science Quarterly 96(1):133-47.

Bierman, Alex. 2010. "Stress Valuation and the Experience of Parenting Stress in Late Life." Pp. 189-205 in Advances in the conceptualization of the stress process: Essays in honor of Leonard I. Pearlin, edited by W. Avison, C. S. Aneshensel, S. Schieman, and B. Wheaton. New York, NY: Springer.

Bonikowski, Bart, and Paul DiMaggio. 2016. "Varieties of American Popular Nationalism." American Sociological Review 81(5):949-80.

Braunstein, Ruth. 2017. "Muslims as Outsiders, Enemies, and Others: The 2016 Presidential Election and the Politics of Religious Exclusion.” American Journal of Cultural Sociology 5(3):355-372.

Braunstein, Ruth, Todd Nicholas Fuist, and Rhys H. Williams, eds. 2017. Religion and Progressive Activism: New Stories about Faith and Politics. New York NY: NYU Press. Braunstein, Ruth, and Malaena Taylor. 2017. "Is the Tea Party a 'Religious' Movement?: Religiosity in the Tea Party versus the Religious Right.” Sociology of Religion 78(1):3359.

Brubaker, Rogers. 2012. "Religion and Nationalism: Four Approaches." Nations and Nationalism 18(1):2-20.

Brubaker, Rogers. 2017. "Between Nationalism and Civilizationism: The European Populist Moment in Comparative Perspective." Ethnic and Racial Studies 40(8):1191-1226. 
Burge, Ryan P. 2020. “How Many ‘Nones’ Are There? Explaining the Discrepancies in Survey Estimates." Review of Religious Research 1-18.

Carney, Timothy P. 2019. Alienated America: Why Some Places Thrive While Others Collapse. New York, NY: Harper.

Castle, Jeremiah J., Geoffrey C. Layman, David E. Campbell, and John C. Green. 2017. "Survey Experiments on Candidate Religiosity, Political Attitudes, and Vote Choice." Journal for the Scientific Study of Religion 56(1):143-161.

Chaves, Mark. 2004. Congregations in America. Cambridge, MA: Harvard University Press.

Chaves, Mark. 2017. American Religion: Contemporary Trends. Princeton, NJ: Princeton University Press.

Delehanty, Jack, Penny Edgell, and Evan Stewart. 2019. “Christian America? Secularized Evangelical Discourse and the Boundaries of National Belonging." Social Forces 97(3):1283-1306.

Djupe, Paul A., Jacob R. Neiheisel, and Kimberly H. Conger. 2018. “Are the Politics of the Christian Right Linked to State Rates of the Nonreligious? The Importance of Salient Controversy." Political Research Quarterly 71(4):910-22.

Domke, David Scott, and Kevin M. Coe. 2010. The God Strategy: How Religion Became a Political Weapon in America. Updated edition. New York, NY: Oxford University Press.

Dougherty, Kevin D., Byron R. Johnson, and Edward C. Polson. 2007. "Recovering the Lost: Remeasuring U.S. Religious Affiliation.” Journal for the Scientific Study of Religion 46(4):483-499.

Douthat, Ross. 2014. “The Christian Penumbra.” New York Times, March 29. 
Edgell, Penny. 2017. “An Agenda for Research on American Religion in Light of the 2016 Election." Sociology of Religion 78(1):1-8.

Edgell, Penny, Douglas Hartmann, Evan Stewart, and Joseph Gerteis. 2016. "Atheists and Other Cultural Outsiders: Moral Boundaries and the Non-Religious in the United States.” Social Forces 95(2):607-38.

Edin, Kathryn, Timothy Nelson, Andrew Cherlin, and Robert Francis. 2019. "The Tenuous Attachments of Working-Class Men." Journal of Economic Perspectives 33(2):211-28.

Ekins, Emily. 2018. Religious Trump Voters: How Faith Moderates Attitudes about Immigration, Race, and Identity. Washington, D.C.: Democracy Fund Voter Study Group.

Franzen, Aaron B. 2013. "Reading the Bible in America: The Moral and Political Attitude Effect." Review of Religious Research 55(3):393-411.

Froese, Paul. 2017. American Values, Mental Health, and Using Technology in the Age of Trump: Findings from the Baylor Religion Survey, Wave 5. Waco, TX: Baylor University.

Froese, Paul, and F. Carson Mencken. 2009. “A US Holy War? The Effects of Religion on Iraq War Policy Attitudes.” Social Science Quarterly 90(1):103-116.

Gorski, Philip S. 2010. Civil Religion Today. State College, PA: The Association of Religion Data Archives.

Gorski, Philip S. 2017. "Why Evangelicals Voted for Trump: A Critical Cultural Sociology." American Journal of Cultural Sociology 5(3):338-354.

Gorski, Philip S. 2019. American Covenant: A History of Civil Religion from the Puritans to the Present. Princeton, NJ: Princeton University Press. 
Gorski, Philip S. 2020. American Babylon: Christianity and Democracy before and after Trump. New York, NY: Routledge.

Griffin, Robert, and Ruy Teixeira. 2017. The Story of Trump's Appeal: A Portrait of Trump Voters. Democracy Fund Voter Study Group.

Hervieu-Léger, Danièle. 2006. "The Role of Religion in Establishing Social Cohesion.” Pp. 4563 in Religion in the new Europe, edited by K. Michalski. New York, NY: Central European University Press.

Hochschild, Arlie Russell. 2018. Strangers in Their Own Land: Anger and Mourning on the American Right. New York, NY: The New Press.

Huang, Jon, Samuel Jacoby, Michael Strickland, and K. K. Rebecca Lai. 2016. "Election 2016: Exit Polls." The New York Times, November 8.

Jones, Robert P. 2016. The End of White Christian America. New York, NY: Simon \& Schuster. Karakaya, Yağmur. 2020. "The Conquest of Hearts: The Central Role of Ottoman Nostalgia within Contemporary Turkish Populism." American Journal of Cultural Sociology 8(2):125-57. doi: 10.1057/s41290-018-0065-y.

Kazyak, Emily, Kelsy Burke, and Mathew Stange. 2018. "Logics of Freedom: Debating Religious Freedom Laws and Gay and Lesbian Rights.” Socius 4:1-18.

Keeter, Scott, Nick Hatley, Courtney Kennedy, and Arnold Lau. 2017. What Low Response Rates Mean for Telephone Surveys. Washington, DC: Pew Research Center.

Kennedy, Courtney, and Hanna Harting. 2019. Response Rates in Telephone Surveys Have Resumed Their Decline. Washington, DC: Pew Research Center.

Kruse, Kevin Michael. 2015. One Nation under God: How Corporate America Invented Christian America. New York, NY: Basic Books. 
Leege, David C., and Lyman A. Kellstedt. 1993. Rediscovering the Religious Factor in American Politics. Armonk, NY: M.E. Sharpe.

Lim, Chaeyoon. 2015. "Religion and Subjective Well-Being Across Religious Traditions: Evidence from 1.3 Million Americans." Journal for the Scientific Study of Religion 54(4):684-701.

Liu, Baodong, Sharon D. Wright Austin, and Byron D’Andra Orey. 2009. “Church Attendance, Social Capital, and Black Voting Participation.” Social Science Quarterly 90(3):576-592.

Major, Brenda, Alison Blodorn, and Gregory Major Blascovich. 2018. "The Threat of Increasing Diversity: Why Many White Americans Support Trump in the 2016 Presidential Election.” Group Processes \& Intergroup Relations 21(6):931-940.

Margolis, Michele F. 2018. From Politics to the Pews: How Partisanship and the Political Environment Shape Religious Identity. Chicago, IL: The University of Chicago Press.

Margolis, Michele F. 2020. "Who Wants to Make America Great Again? Understanding Evangelical Support for Donald Trump." Politics and Religion 13(1):89-118.

Marti, Gerardo. 2020. "White Christian Libertarianism and the Trump Presidency." Pp. 19-40 in Religion is raced: understanding American religion in the twenty-first century, edited by G. Yukich and P. Edgell. New York: New York University Press.

Mize, Trenton D. 2019. “Best Practices for Estimating, Interpreting, and Presenting Nonlinear Interaction Effects." Sociological Science 6:81-117.

Mutz, Diana C. 2018. "Status Threat, Not Economic Hardship, Explains the 2016 Presidential Vote." Proceedings of the National Academy of Sciences 115(19):E4330-E4339.

Norton, Michael I., and Samuel R. Sommers. 2011. “Jockeying for Stigma." New York Times, May 23. 
O’Brien, John, and Eman Abdelhadi. 2020. “Re-Examining Restructuring: Racialization, Religious Conservatism, and Political Leanings in Contemporary American Life.” Social Forces.

Parker, Christopher S., and Matt A. Barreto. 2014. Change They Can't Believe in: The Tea Party and Reactionary Politics in America. Princeton, NJ: Princeton University Press.

Schaffner, Brian F., Matthew Macwilliams, and Tatishe Nteta. 2018. "Understanding White Polarization in the 2016 Vote for President: The Sobering Role of Racism and Sexism." Political Science Quarterly 133(1):9-34.

Schieman, Scott, Alex Bierman, and Christopher G. Ellison. 2013. "Religion and Mental Health.” Pp. 457-478 in Handbook of the Sociology of Mental Health, edited by C. S. Aneshensel, J. C. Phelan, and A. Bierman. New York, NY: Springer.

Schwadel, Philip. 2020. “The Politics of Religious Nones.” Journal for the Scientific Study of Religion 59(1):180-189.

Sides, John, Michael Tesler, and Lynn Vavreck. 2018. Identity Crisis: The 2016 Presidential Campaign and the Battle for the Meaning of America. Princeton, NJ: Princeton University Press.

Smidt, Corwin E. 2017. "The Role of Religion in the 2016 American Presidential Election.” Zeitschrift Für Religion, Gesellschaft Und Politik 1(1):133-62.

Steensland, Brian, and Philip Goff. 2013. The New Evangelical Social Engagement. New York, NY: Oxford University Press.

Steensland, Brian, Jerry Z. Park, Lynn D. Robinson, W. Bradford Wilcox, and Robert D. Woodberry. 2000. "The Measure of American Religion: Toward Improving the State of the Art." Social Forces 79(1):291-318. 
Storm, Ingrid. 2011. "Christian Nations? Ethnic Christianity and Anti-Immigration Attitudes in Four Western European Countries.” Nordic Journal of Religion and Society 24(1):75-96.

Stroope, Samuel. 2012. "Social Networks and Religion: The Role of Congregational Social Embeddedness in Religious Belief and Practice." Sociology of Religion 73(3):273-98. doi: $10.1093 /$ socrel/srr052.

Stroope, Samuel, Mark H. Walker, and Aaron B. Franzen. 2017. "Stress Buffer or Identity Threat? Negative Media Portrayal, Public and Private Religious Involvement, and Mental Health in a National Sample of US Adults." Society and Mental Health 7(2):85-104.

Thomson, Robert A., and Paul Froese. 2018. "God, Party, and the Poor: How Politics and Religion Interact to Affect Economic Justice Attitudes." Sociological Forum 33(2):33453.

Tranby, Eric, and Douglas Hartmann. 2008. "Critical Whiteness Theories and the Evangelical 'Race Problem': Extending Emerson and Smith's Divided by Faith.” Journal for the Scientific Study of Religion 47(3):341-59.

U.S. Census Bureau. 2014. 2013 American Community Survey and Puerto Rico Community Survey 2014 Subject Definitions. Washington, D.C.: U.S. Census Bureau. Voas, David, and Mark Chaves. 2016. "Is the United States a Counterexample to the Secularization Thesis?” American Journal of Sociology 121(5):1517-1556.

Voas, David, and Mark Chaves. 2018. "Even Intense Religiosity Is Declining in the United States: Comment.” Sociological Science 5:694-710.

Voas, David, and Abby Day. 2010. Recognizing Secular Christians: Toward an Unexcluded Middle in the Study of Religion. Association of Religion Data Archives. 
Wald, Kenneth D., and Allison Calhoun-Brown. 2018. Religion and Politics in the United States. Eighth edition. Lanham, MD: Rowman \& Littlefield Publishers.

Wayne, Carly, Nicholas Valentino, and Marzia Oceno. 2016. "How Sexism Drives Support for Donald Trump.” Washington Post, October 23.

Whitehead, Andrew L., and Samuel L. Perry. 2020. Taking America Back for God: Christian Nationalism in the United States. New York, NY: Oxford University Press.

Whitehead, Andrew L., Samuel L. Perry, and Joseph O. Baker. 2018. "Make America Christian Again: Christian Nationalism and Voting for Donald Trump in the 2016 Presidential Election." Sociology of Religion 79(2):147-171.

Wilcox, Clyde, and Carin Robinson. 2011. Onward Christian Soldiers? The Religious Right in American Politics. 4th ed. Boulder, CO: Westview Press.

Wilcox, W. Bradford, Andrew J. Cherlin, Jeremy E. Uecker, and Matthew Messel. 2012. "No Money, No Honey, No Church: The Deinstitutionalization of Religious Life among the White Working Class." Research in the Sociology of Work 23:227-250.

Williams, Rhys H. 2013. "Civil Religion and the Cultural Politics of National Identity in Obama's America." Journal for the Scientific Study of Religion 52(2):239-57.

Wuthnow, Robert. 2012. Red State Religion: Faith and Politics in America's Heartland. Princeton, NJ: Princeton University Press. 
Table 1. Distributions and Multivariable Associations Between Predictors and Voting for Trump

\begin{tabular}{|c|c|c|c|c|c|c|c|c|}
\hline \multirow[b]{3}{*}{ Christian nationalism (A) } & \multicolumn{2}{|c|}{ Distribution } & \multicolumn{2}{|c|}{ Model 1} & \multicolumn{4}{|c|}{ Model 2} \\
\hline & $\mathrm{M} / \%$ & SD & OR & SE & & OR & $\mathrm{SE}$ & \\
\hline & 0.33 & 6.65 & 1.09 & 0.05 & & 1.28 & 0.09 & $* * *$ \\
\hline Non-attender (ref.) & $28.4 \%$ & & & & & & & \\
\hline Occasional attender (B) & $29.2 \%$ & & 0.55 & 0.26 & & 0.40 & 0.20 & \\
\hline Regular attender $(\mathrm{C})$ & $42.4 \%$ & & 1.15 & 0.64 & & 1.29 & 0.73 & \\
\hline $\mathrm{A} \times \mathrm{B}$ & & & & & & 0.87 & 0.08 & \\
\hline $\mathrm{A} \times \mathrm{C}$ & & & & & & 0.76 & 0.06 & $* *$ \\
\hline Prayer & 2.64 & 1.86 & 1.42 & 0.17 & $* *$ & 1.39 & 0.16 & $* *$ \\
\hline Scripture reading & 2.69 & 2.85 & 0.80 & 0.06 & $* *$ & 0.83 & 0.06 & $*$ \\
\hline Biblical literalism & $18.4 \%$ & & 0.81 & 0.34 & & 0.87 & 0.37 & \\
\hline Evangelical Protestant (ref.) & $29.4 \%$ & & & & & & & \\
\hline Mainline Protestant & $12.3 \%$ & & 1.01 & 0.44 & & 1.00 & 0.44 & \\
\hline Catholic & $25.1 \%$ & & 0.93 & 0.35 & & 0.96 & 0.36 & \\
\hline Other faith & $15.3 \%$ & & 0.39 & 0.18 & $*$ & 0.40 & 0.17 & $*$ \\
\hline None & $17.9 \%$ & & 0.81 & 0.55 & & 1.29 & 0.96 & \\
\hline Age & 50.56 & 16.85 & 1.00 & 0.01 & & 1.00 & 0.01 & \\
\hline Female & $52.2 \%$ & & 0.79 & 0.28 & & 0.83 & 0.29 & \\
\hline Non-Hispanic White & $71.1 \%$ & & 2.59 & 0.94 & $* *$ & 2.77 & 0.97 & $* *$ \\
\hline Married & $52.4 \%$ & & 1.11 & 0.36 & & 1.16 & 0.37 & \\
\hline Less than high school & $25.8 \%$ & & 1.16 & 0.99 & & 1.11 & 0.87 & \\
\hline High school (ref.) & $6.9 \%$ & & & & & & & \\
\hline Some college & $32.0 \%$ & & 1.54 & 0.66 & & 1.58 & 0.69 & \\
\hline College or more & $35.2 \%$ & & 0.90 & 0.43 & & 0.86 & 0.43 & \\
\hline Income & 4.38 & 1.63 & 1.35 & 0.15 & $* *$ & 1.38 & 0.15 & $* *$ \\
\hline Republican (ref.) & $30.7 \%$ & & & & & & & \\
\hline Independent & $30.8 \%$ & & 0.29 & 0.08 & $* * *$ & 0.25 & 0.07 & $* * *$ \\
\hline Democrat & $38.5 \%$ & & 0.03 & 0.02 & $* * *$ & 0.03 & 0.01 & $* * *$ \\
\hline Political conservatism & 4.15 & 1.61 & 2.15 & 0.33 & $* * *$ & 2.35 & 0.38 & $* * *$ \\
\hline Anti-Muslim attitudes & 8.62 & 3.34 & 1.19 & 0.09 & $*$ & 1.21 & 0.08 & $* *$ \\
\hline Anti-immigrant attitudes & 1.72 & 0.67 & 2.39 & 0.78 & $* *$ & 2.27 & 0.76 & $*$ \\
\hline Anti-black attitudes & 4.28 & 1.41 & 1.02 & 0.13 & & 1.03 & 0.14 & \\
\hline Gender ideology & 7.27 & 2.48 & 0.98 & 0.08 & & 0.97 & 0.08 & \\
\hline Economic satisfaction & 3.12 & 1.00 & 0.80 & 0.16 & & 0.78 & 0.15 & \\
\hline Intercept & & & 0.00 & 0.00 & $* * *$ & 0.00 & 0.00 & $* * *$ \\
\hline
\end{tabular}

Note: $N=1,242 ; \mathrm{M}=$ mean; $\mathrm{SD}=$ standard deviation; $\mathrm{OR}=$ odds ratio; $\mathrm{SE}=$ standard error; analysis is weighted; Models control region and urbanicity (not displayed for brevity); ${ }^{*} p<.05 ; * * p<.01 ; * * * p<.001$ 


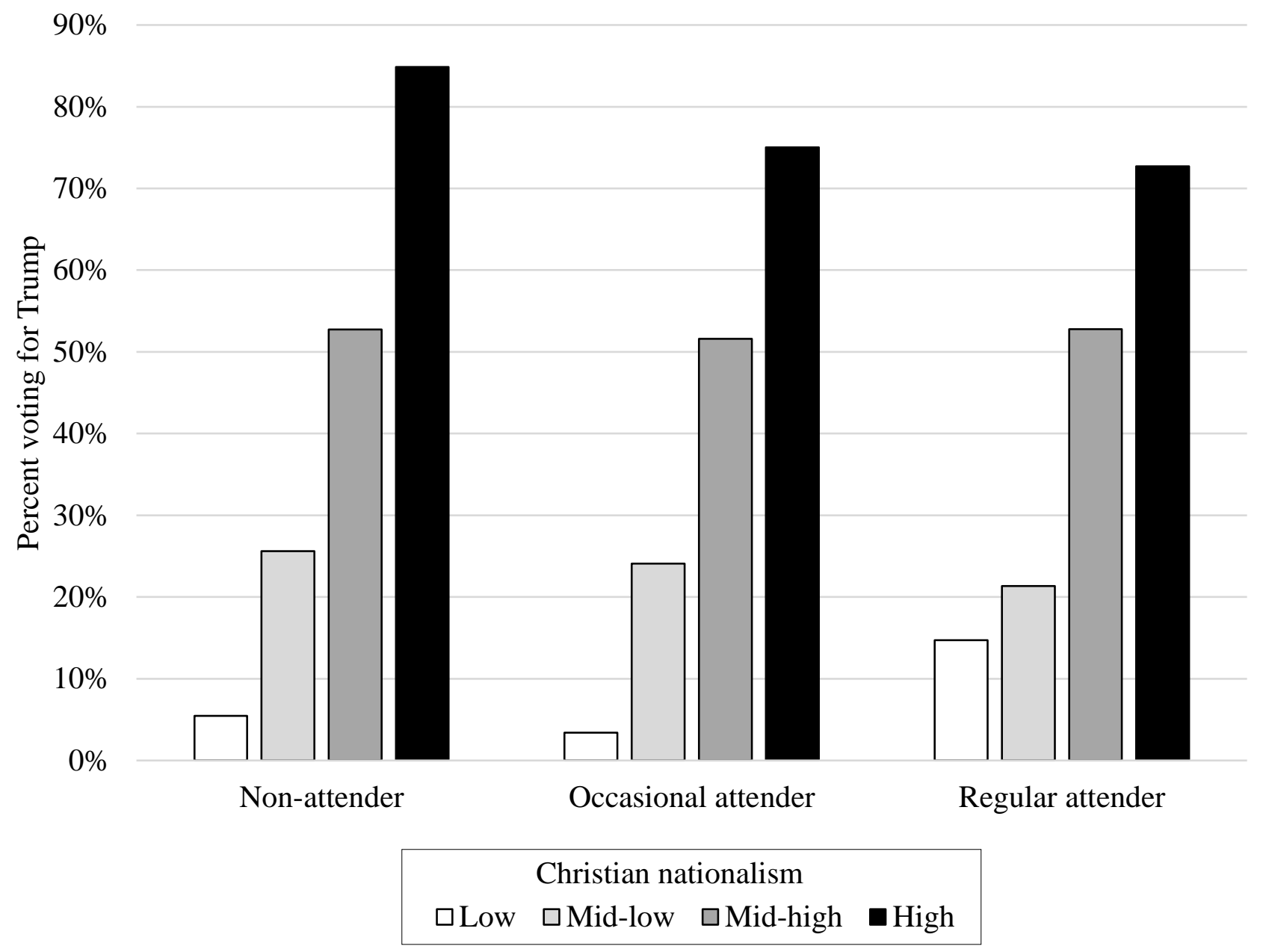

NOTE: Christian nationalism is binned into four levels corresponding to Whitehead and Perry (2020). Weighted trivariate distribution presented using multiply imputed data.

Figure 1. Percent voting for Trump by religious service attendance and Christian nationalism 


\section{Panel A. Average Marginal Effects (AME)}

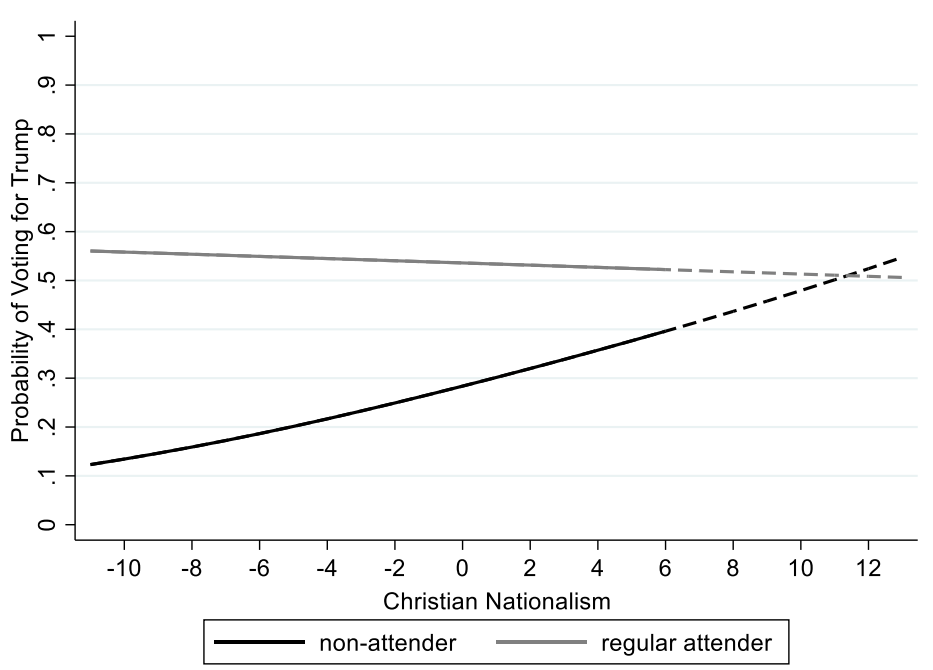

Panel C. Predicted Probabilities for Moderate Independents

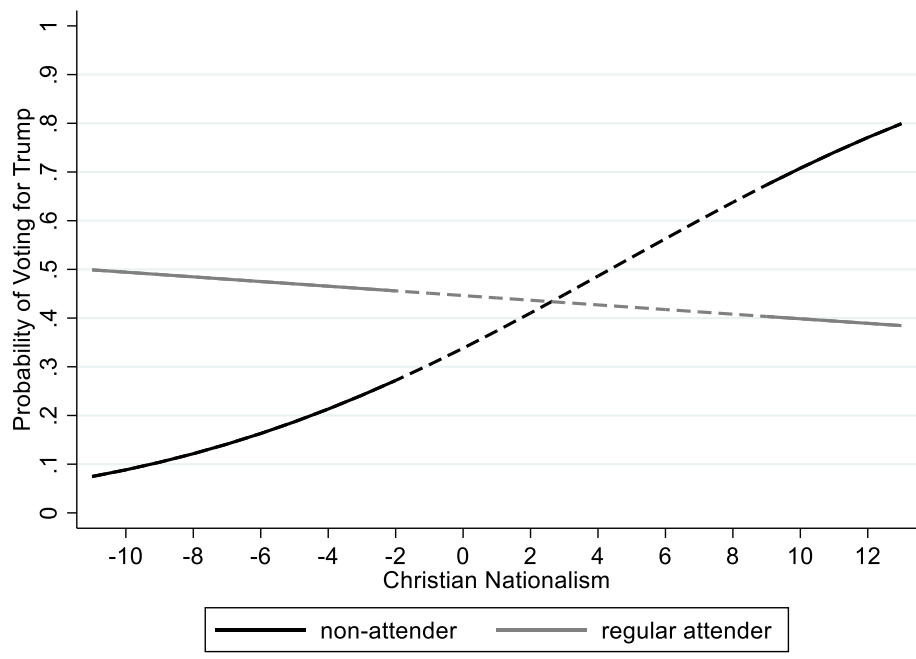

Panel B. Predicted Probabilities for Moderate Republicans

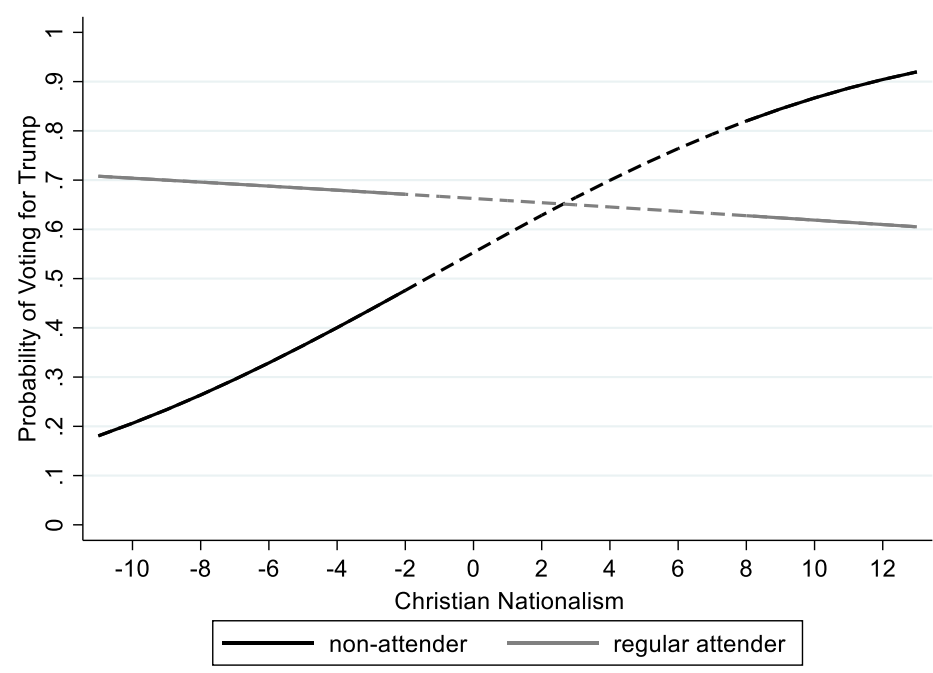

Panel D. Predicted Probabilities for Moderate Democrats

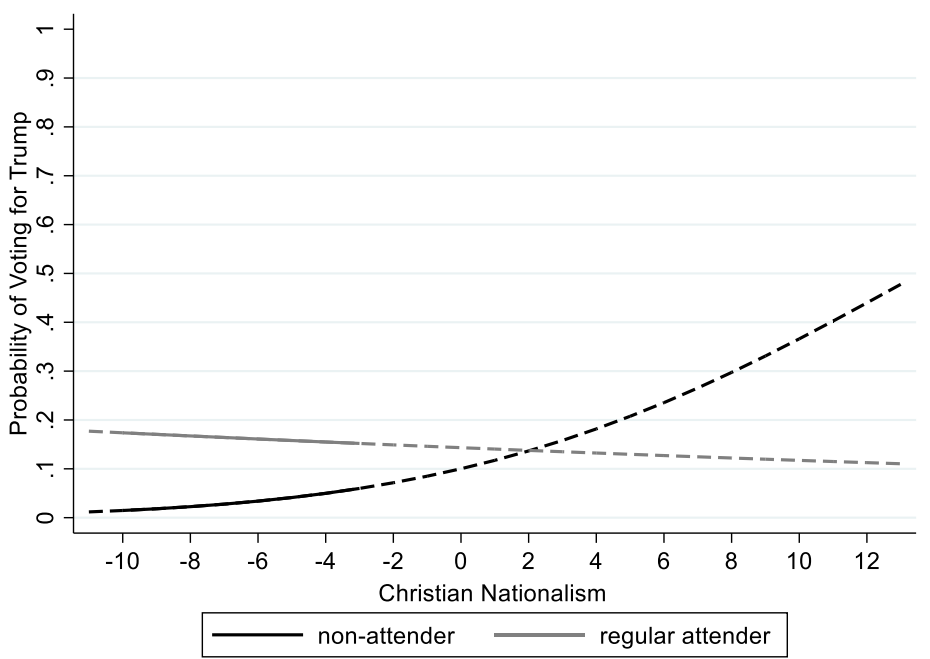

Figure 2. Trump voting by religious attendance and Christian nationalism; Attendance difference is $p<.05$ when lines are solid. 